Crop Breeding and Applied Biotechnology 14: 224-231, 2014

Brazilian Society of Plant Breeding. Printed in Brazil

\title{
ARTICLE
}

http://dx.doi.org/10.1590/1984-70332014v14n4a35

\section{Genetic divergence among Brachiara humidicola (Rendle) Schweick hybrids evaluated in the Western Brazilian Amazon}

\author{
Giselle Mariano Lessa de Assis ${ }^{1 *}$, Cléia Florentino dos Santos ${ }^{2}$, Patrícia Silva Flores ${ }^{1}$ and Cacilda Borges do Valle ${ }^{3}$
}

Received 16 February 2014

Accepted 29 April 2014

\begin{abstract}
The objectives of this study were to detect genetic variability among genotypes of Brachiara humidicola, study the genetic diversity and identify redundant variables in the discrimination of hybrids. Fifteen genotypes were evaluated for morphological, agronomic and nutritive characteristics in a randomized block design with six replications, in Rio Branco, Acre. Analysis of variance was performed, followed by the Scott-Knott test. Different techniques of multivariate analysis were used to study genetic diversity. Significant differences in plant performance were observed for agronomic and morphological characteristics, but not for nutritive value. There was consistency between the different clustering techniques. Four redundant characteristics were identified that can be discarded. The existence of divergent and superior hybrids that can be used in recurrent selection (sexual) programs or can be released as new (apomictic) cultivars after testing for animal response was confirmed. The lack of genetic variability in bromatological traits indicates the need for differentiated selection strategies.
\end{abstract}

Key words: Forage breeding, nutritive value, multivariate analysis, tropical forages.

\section{INTRODUCTION}

In Brazil, the systems of meat and milk production are mainly based on pasture, mostly with grasses of the genus Brachiara. This genus is cultivated on an estimated area of over 100 million ha (Macedo et al. 2006), with predominantly species of Brachiara brizantha (A. Rich.) Stapf, Brachiara decumbens Stapf and Brachiara humidicola (Rendle) Schweick (Synonyms: Urochloa brizantha, Urochloa decumbens, and Urochloa humidicola, respectively).

Brachiara humidicola, commonly known as koronivia grass, humidicola, creeping signal grass (Australia), or false creeping paspalum (English), is a species native to Africa, tolerant to intensive grazing and shade and easily adaptable to acidic, low-fertility and poorly drained soils (Keller-Grein et al. 1996). This tolerance to waterlogged soils is an important factor for the Brazilian livestock production systems, particularly in the Amazon ecosystem, where the death syndrome of $B$. brizantha $\mathrm{cv}$. Marandu in poorly drained soils has contributed greatly to pasture degradation and the loss of productive capacity (Dias-Filho 2006). Despite its low nutritional value, in pasture intercropped with legumes, koronivia grass results in satisfactory bodyweight gain (Barcellos et al. 2008, Carvalho and Pires 2008).

Although new tropical forage cultivars have been released in the last 10 years, the genetic base of the cultivated $\mathrm{Bra}$ chiara is still narrow (Assis et al. 2003). This fact, coupled with the occurrence of apomixis, which is characterized by the development of the embryo from an unfertilized cell, has hampered the increase in genetic variability of this genus and maintained the genetic vulnerability of Brazilian pastures high (Assis et al. 2003, Jungmann et al. 2010).

The intraspecific hybridization of $B$. humidicola became possible after the discovery of a sexual accession (H031) in the Active Germplasm Bank of Brachiara of Embrapa Beef Cattle (Valle and Glienke 1991). However, only recently, crosses were made between cultivar BRS Tupi and sexual accession H031, both hexaploid $(2 \mathrm{n}=6 \mathrm{x}=36)$, which led to the development of 364 full-sib progenies (Figueiredo et al. 2012), segregating in a proportion of $1: 1$ for reproduction mode (sexual and apomictic) (Zorzatto et al. 2010). These sexual and apomictic hybrid progenies were evaluated and selected in Campo Grande and 14 were sent to Acre for

\footnotetext{
${ }^{1}$ Embrapa Acre, Rodovia BR 364, km 14, CP 321, 69.900-970, Rio Branco, AC, Brazil. *E-mail: giselle.assis@embrapa.br

${ }^{2}$ Universidade Federal do Acre, Campus Universitário, BR 364, Km 04, Distrito Industrial, 69.920-900, Rio Branco, AC, Brazil

${ }^{3}$ Embrapa Gado de Corte, Av. Rádio Maia, 830, Zona Rural, 79.106-550, Campo Grande, MS, Brazil
} 
testing under the soil-climatic conditions of the Western Brazilian Amazon.

Since this was the first descendant of an intraspecific cross in B. humidicola, the level of genetic diversity among the full-sib progenies is still unknown. This knowledge is required to make decisions on crosses in the program of recurrent selection and selection of apomictic hybrids, thus avoiding the need for evaluations with animals and the release of new, but genetically similar cultivars. The characterization of elite germplasm, as well as knowledge on the genetic basis of variability are important in the design of a breeding program focused on the possible exploitation of heterosis in B. humidicola (Jungmann et al. 2010).

The objectives of this study were to detect genetic variability among $B$. humidicola genotypes, study the genetic divergence between hybrids and identify redundant and irrelevant variables in the discrimination of the genotypes.

\section{MATERIAL AND METHODS}

The experiment was carried out in the experimental field of Embrapa Acre, Rio Branco, Acre, Brazil (lat 9० 58' 22" S, long $67^{\circ} 48^{\prime} 40^{\prime \prime} \mathrm{W}$, alt $160 \mathrm{~m}$ asl) in December 2008, on a dystrophic red latosol (oxisol). The annual mean temperature is $24.5^{\circ} \mathrm{C}$, the relative air humidity $80-90 \%$, and the average annual rainfall $1877-1982 \mathrm{~mm}$; there is a rainy season from October to April and a dry season from June to September (Acre 2006). The soil of the study area was limed with dolomitic limestone (0.86 tha $\left.{ }^{-1}, \mathrm{PRNT}=100 \%\right)$ and fertilized with triple superphosphate $\left(50 \mathrm{~kg} \mathrm{ha}^{-1} \mathrm{P}_{2} \mathrm{O}_{5}\right)$, potassium chloride $\left(40 \mathrm{~kg} \mathrm{ha}^{-1} \mathrm{~K}_{2} \mathrm{O}\right)$ and micronutrients (40 $\mathrm{kg} \mathrm{ha}^{-1}$ of FTE BR12), as indicated by the results of soil analysis. Fifteen genotypes of Brachiara humidicola from Embrapa Beef Cattle were evaluated, of which 14 were full-sib hybrids and one a control called cv. Comum (eight apomictic and seven sexual). The experiment was arranged in a randomized block design with six replications, evaluating an area of $3 \mathrm{~m}^{2}$ per plot.

Agronomic, morphological and qualitative characteristics were evaluated. The agronomic evaluations started after cuts for uniformity and eight cuts were made in two consecutive years (2009-2011). Two cuts were performed in the dry and six cuts in the rainy season. The traits dry matter yield (DMY, kg ha-1 ${ }^{-1} \mathrm{year}^{-1}$ ), leaf dry matter yield (LDMY, $\mathrm{kg} \mathrm{ha}^{-1}$ year $^{-1}$ ) and plant height ( $\mathrm{PH}, \mathrm{cm}$ ) were evaluated.

Morphological characterization was performed in the rainy season, before the first uniformity cut in 2009 . The morphological traits were leaf blade length $(\mathrm{cm})$, blade width $(\mathrm{cm})$, sheath length $(\mathrm{cm})$, flower stem length $(\mathrm{cm})$, inflorescence stem length $(\mathrm{cm})$, number of racemes, basal raceme length $(\mathrm{cm})$ and number of spikelets in the basal raceme.

The chemical analyses were carried out using samples of five cuts, two in the dry period and three in the rainy season. The following qualitative characteristics were evaluated: crude protein (CP, $\%$ of dry matter - DM), neutral detergent fiber (NDF, $\%$ of DM), acid detergent fiber (ADF, $\%$ of DM) and lignin (LIG, $\%$ of $\mathrm{DM}$ ).

Analysis of variance was performed for all traits and then the Scott-Knott test (Scott and Knott 1974) was applied for characteristics with variability between genotypes. The heritability of each trait was estimated based on the treatment means.

The genetic diversity was assessed by three different multivariate analysis techniques in order to support the discussion on clustering, allowing to check the consistency between methodologies, considering the different criteria that are likely to produce different results. First, similarity measures between genotypes were obtained by Mahalanobis distance, including all traits with variability between genotypes by analysis of variance. Based on the estimated distances, three techniques were applied (Cruz et al. 2012): Tocher optimization, hierarchical nearest neighbor and the canonical variate analysis. The group based on the scores of the canonical variables was defined by the Tocher method, using Euclidean distances of the scores of the first three canonical variables of genotypes. After the first analysis cycle, which resulted in the formation of only two groups (one with the control and the other with all hybrids), we proceeded to the second cycle using the group consisting of all hybrids by subjecting them again to three multivariate analysis techniques, aiming at the formation of subgroups.

To determine the relative importance of traits for discriminating genotype performance and clustering, the characters with highest absolute weighting coefficients (eigenvector), obtained with the standardization of the variables, were identified in the last canonical variables (Cruz et al. 2012). These characteristics were successively identified until the corresponding eigenvalue that did not exceed 0.70 (Jollife 1972). Once the traits with less relative importance for genetic divergence were identified, they were eliminated, each one separately and all at the same time, and then the hybrids clustered by the Tocher method, to compare how the elimination of the characteristic(s) affected the groupings. Additionally, the genotypic correlation coefficients between traits were estimated. Analyses were performed with the Genes software (Cruz 2006). 


\section{RESULTS AND DISCUSSION}

According to the analysis of variance significant differences were observed for all characteristics between the $B$. humidicola genotypes, except for the bromatological traits (crude protein, neutral detergent fiber, acid detergent fiber, and lignin content) (Table 1). The lack of variability for the studied bromatological characteristics, as the hybrids did not differ from each other nor from cv. Comum, indicates the need for differentiated strategies by the search of genetic variability for these characteristics. $B$. humidicola is traditionally known for its low nutritional value compared with other forage grasses (Lascano and Euclides 1996), making it a challenge for breeders to develop cultivars of this species with higher nutritional value, especially with higher crude protein. The low crude protein content of $B$. humidicola is a disadvantage of this grass, since contents of less than 6-7\% can drastically reduce consumption (Minson and Milford 1967). According to Reis and Silva (2006) in forages with less than $10 \% \mathrm{CP}$, the microbial protein synthesis is limited, probably due to the lack of amino acid, ammonia and energy for microorganisms of the rumen. As observed in Table 1, the mean crude protein content of the B. humidicola genotypes was only $7.23 \%$. In the selection of genotypes in the early evaluation stages of breeding programs great emphasis has been given to characters of forage production (dry matter yield, leaf dry matter yield, leaf percentage, leaf/stem ratio). In the particular case of $B$. humidicola, traits related to the nutritional value of the forage should also be included in the initial selection stages. High negative correlations between agronomic and nutritive value characteristics have been reported for this forage species (Reyes-Purata et al. 2009, Figueiredo et al. 2012), so the breeder should seek efficient selection indices to minimize this problem. In the evaluation of $50 \mathrm{~B}$. humidicola hybrids by Figueiredo et al. (2012) in Campo Grande, MS, genetic variability was observed for bromatological characteristics, unlike in this study.

The experimental coefficients of variation were medium to low, indicating good experimental accuracy for all traits (Table 1). The ratio between the coefficients of genetic (CVg) and experimental variation $(\mathrm{CVe})$ was greater than the unity for plant height, blade width, basal raceme length and leaf dry matter yield (Table 1). For these traits, high heritability $(>80 \%$ ) was estimated, indicating that the nature of most of the observed variation for these traits is genetic. These findings show a very favorable situation for selection of important agronomic traits, such as plant height and leaf dry matter yield. Figueiredo et al. (2012) observed heritability

Table 1. Summary of the descriptive analyses and analysis of variance for the 15 studied traits in 15 Brachiaria humidicola genotypes

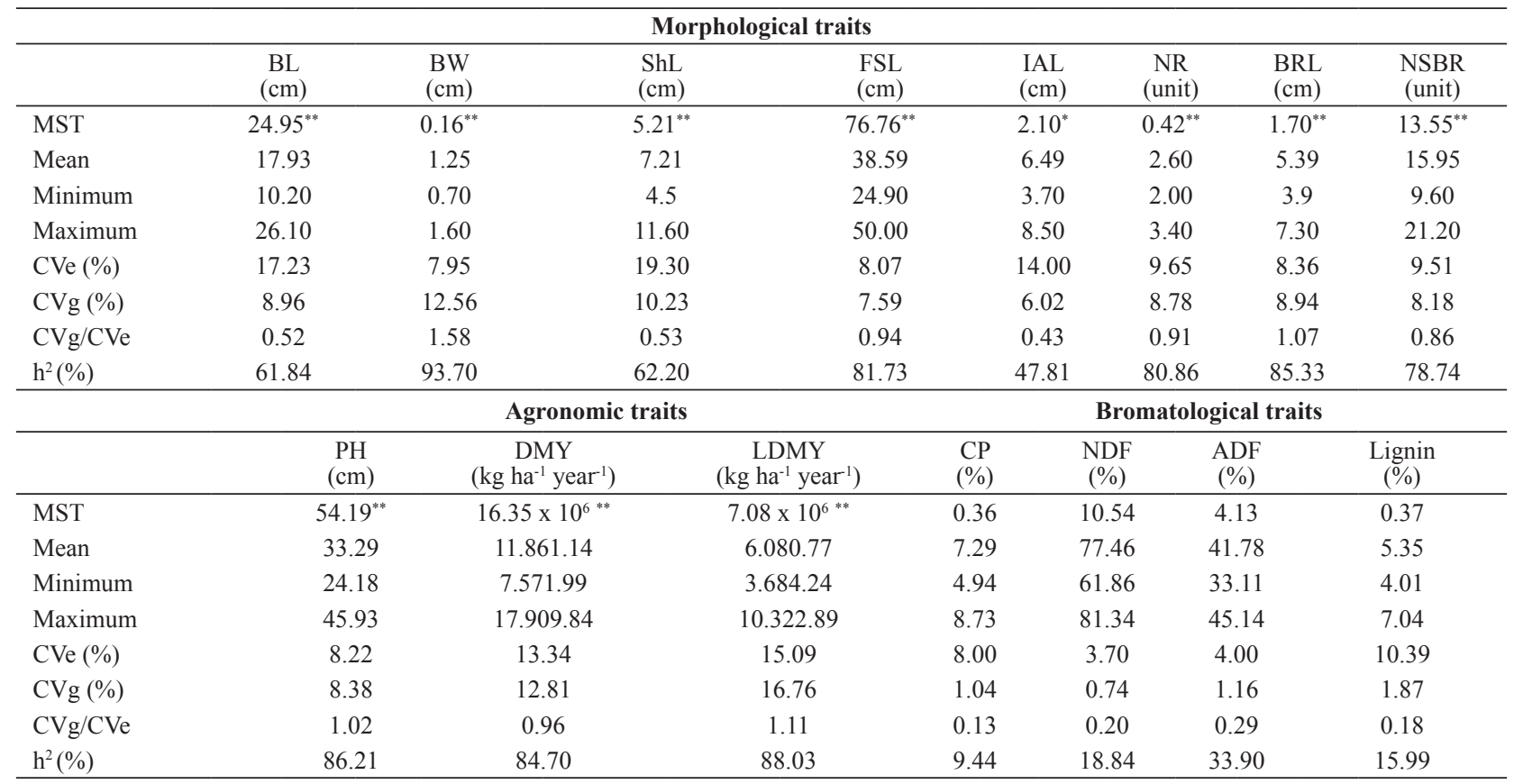

MST: mean square of the treatment; CVe: coefficient of experimental variation; CVg: coefficient of genetic variation; $\mathrm{h}^{2}: \mathrm{mean}$ heritability.

$*$ and $* *$ : significant at $5 \%$ e $1 \%$ probability by the $\mathrm{F}$ test, respectively.

PH: plant height; CP: crude protein; NDF: neutral detergent fiber; ADF: acid detergent fiber; BL: blade length; BW: blade width; ShL: Sheath length; FSL: flower stem length; IAL: inflorescence axis length; NR: number of racemes; BRL: basal raceme length; NSBR: number of spikelets in the basal raceme; DMY: dry matter yield; LDMY: leaf dry matter yield. 
values for leaf dry matter yield and total dry matter yield in B. humidicola progenies of $59.17 \%$ and $69.11 \%$, respectively. In this study, the values were $84.7 \%$ (DMY) and $88.03 \%$ (LDMY), indicating an efficient control of the experimental environment. The bromatological characteristics (CP, NDF, $\mathrm{ADF}$, lignin) had the lowest estimates of the ratio $\mathrm{CVg} / \mathrm{CVe}$ and the determination coefficient, indicating less genotypic variability. Since no significant differences between the genotypes were observed for these characteristics, they were not used in the studies of genetic divergence.

After detecting significant differences for 11 of the 15 traits evaluated, the genetic divergence between genotypes was assessed by multivariate analysis. By the Tocher grouping method, 15 genotypes were divided into only two groups, whereas the control, represented by cv. Comum, was separated in a group of its own and all hybrids within the second group. The same grouping pattern was observed with hierarchical nearest neighbor and canonical variate analysis. These results indicate high divergence between the control and the other genotypes, so that the techniques could not discriminate the hybrids. It is worth emphasizing that these hybrids are full-sib progenies from a cross between $\mathrm{H} 031$ and BRS Tupi (Figueiredo et al. 2012), which have no closer relatedness to $\mathrm{cv}$. Comum, contributing to the isolation of the control in a group. Therefore, the results support the parents H031 and BRS Tupi, which are hexaploid and have 36 chromosomes $(2 n=6 x=36)$, are genetically distant from cv. Comum, which has 54 chromosomes $(2 n=9 x=54)$ (Boldrini et al. 2011). In this way, the group formed by the hybrids was subjected again to analyses of genetic divergence and clustering (second cycle), for the formation of subgroups. The strategy of forming subgroups from groups with a large number of genotypes is being tested by other authors
(Shimoya et al. 2002, Azevedo et al. 2011).

When analyzing the hybrids, high agreement was observed between the groups formed by the Tocher (four groups) and nearest neighbor method (five groups) (Figure 1). By the Tocher method, the hybrids PL029, PL185, PL088, PL111, PL193, PL350, PL297, PL146, and PL289 formed group I; PL064 and PL242 group II; PL138 and PL216 group III; and PL003 group IV. An exception were the hybrids PL138 and PL216, which formed group III by Tocher clustering and two separate groups (III and IV) by the nearest neighbor method. For the method of canonical variables, a scatter plot was created based on the scores of the first three canonical variables (Figure 2), which accounted for $69.99 \%$ of the total variation. The criterion used to group

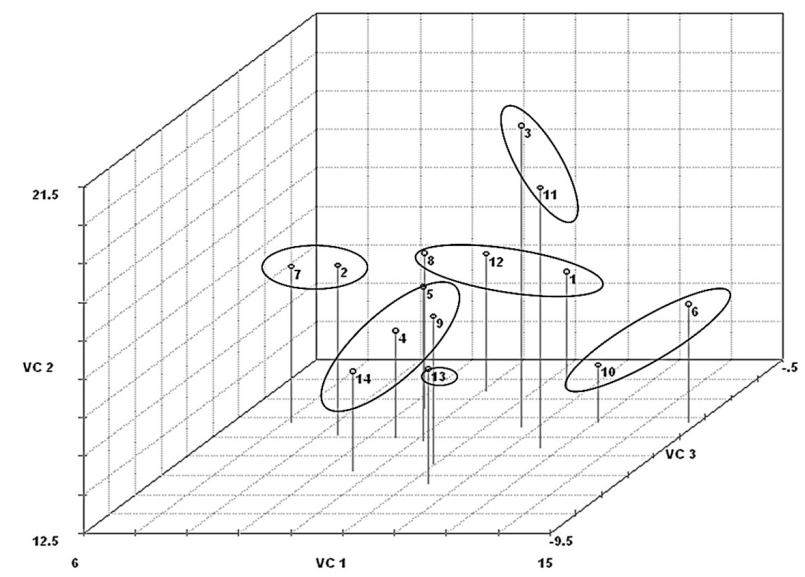

Figure 2. Scatter plot of 14 Brachiaria humidicola hybrids representing the three first canonical variables (VC1, VC2 e VC3). Hybrid identification: 1: PL003; 2: PL029; 3: PL064; 4: PL88 5:PL111; 6: PL138; 7: PL146; 8: PL185; 9: PL193; 10: PL216; 11: PL242; 12: PL289; 13: PL297; 14: PL350.

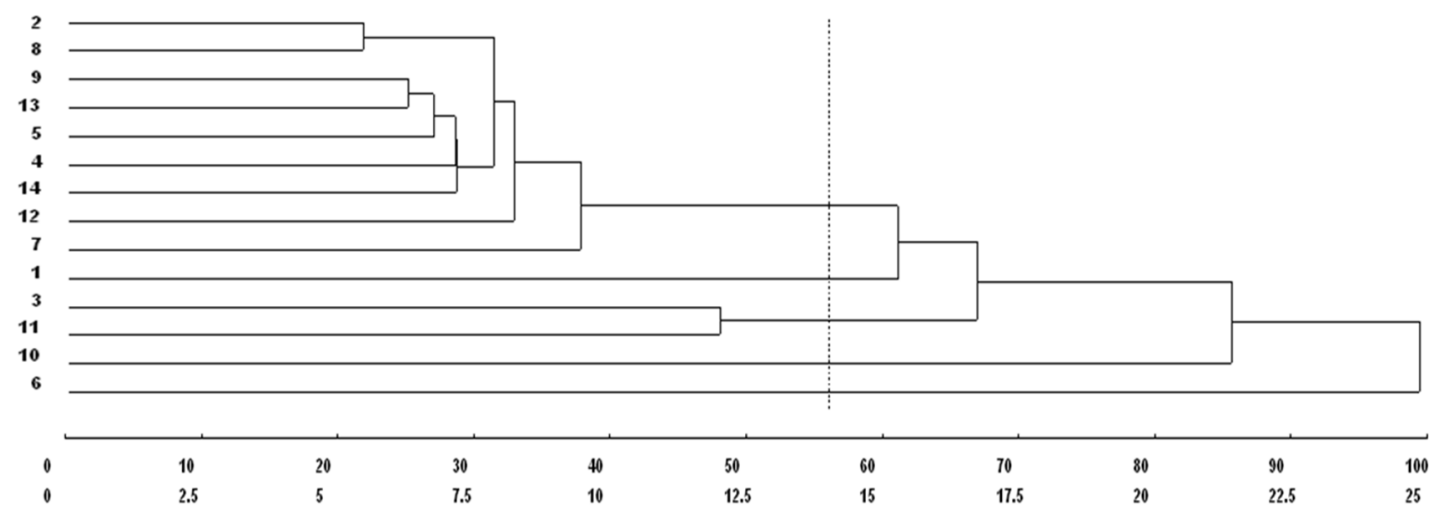

Figure 1. Dendrogram of genetic similarities between Brachiaria humidicola hybrids based on the hierarchical nearest neighbor method, using the Mahalanobis distance. Hybrid identification: 1:PL003; 2: PL029; 3: PL064; 4: PL88 5:PL111; 6: PL138; 7: PL146; 8: PL185; 9: PL193; 10: PL216; 11: PL242; 12: PL289; 13: PL297; 14: PL350. 
the hybrids (Tocher method based on the Euclidean distance of the scores of the first three canonical variables) resulted in the formation of six groups, also with good agreement with the Tocher and nearest neighbor clustering. However, greater discrimination power of the hybrids was observed for the method of canonical variables for separating a higher number of groups, mainly by subdividing the hybrids allocated to group I by the previous methods.

The results indicate the existence of promising genotypes to be used in breeding programs of recurrent selection, particularly the sexual hybrids PL216 and PL289 (Table 2), which were grouped in different clusters consistently by the different methods of genotype grouping, aside from having higher leaf dry matter yield, according to the Scott-Knott test at 5\% probability. Of the apomictic hybrids, PL193, PL242 and PL088 performed especially well for this trait, which can be selected for testing the animal response, with the possibility of being released as new cultivars if their performance is continuously superior to the controls. It is noteworthy that PL242 was always allocated in other groups than PL193 and PL088 and the last two were separated by the method in the canonical variable groups. Assis et al. (2013) showed the ranking of $B$. humidicola genotypes based on the selection index obtained from the genotypic values predicted by the Best Linear Unbiased Prediction (BLUP) for agronomic traits for the Amazon ecosystem. According to these authors, nine hybrids performed better than cv. Comum, four of which were apomictic (PL193, PL242, PL146, and PL88) and five sexual (PL216, PL289,
PL297, PL350, and PL185). These results confirm our results and further expand the possibility of selecting a larger number of hybrids, for the recurrent selection program as well as for the selection of apomictic hybrids, since most of the selected hybrids were divergent, especially when the results obtained by the method of canonical variables were taken into consideration (Figure 2).

Figueiredo et al. (2012) evaluated B. humidicola hybrids of the Cerrado region and identified the best 10 based on selection indices, six of which also stood out under the soilclimatic conditions of Rio Branco, AC. The male parent (cv. BRS Tupi) of the hybrids used in this study was evaluated and recommended for the biomes Cerrado, Amazon and Atlantic Forest (Barbosa 2012) for their superiority in animal response when compared with cv. Comum. On the other hand, the female parent (H031) was used for having a sexual reproduction mode, allowing artificial hybridization and the generation of genetic variability. The agronomic performance of the female parent H031 was lower than the average of other genotypes in an evaluation in Campo Grande by Figueiredo et al. (2012). On the other hand, the female parent $\mathrm{H} 031$ performed better for the characters related to nutritional value, such as crude protein, neutral detergent fiber and in vitro digestibility of leaf organic matter. However, the selection indices used in the assessment in the first cycle of selection resulted in negative genetic gains for crude protein and in vitro digestibility of leaf organic matter. To date, the intraspecific hybridization in $B$. humidicola can only be made between hexaploid accessions

Table 2. Means of agronomic and morphological characteristics of Brachiaria humidicola hybrids evaluated for two years (2009 and 2010)

\begin{tabular}{lccccccccccc}
\hline Genotype* & PH & BL & BW & ShL & FSL & IAL & NR & BRL & NSBR & DMY & LDMY \\
\hline PL003 (A) & $33.0 \mathrm{c}$ & $16.0 \mathrm{~b}$ & $1.0 \mathrm{c}$ & $6.4 \mathrm{~b}$ & $35.7 \mathrm{~b}$ & $6.78 \mathrm{a}$ & $3.0 \mathrm{a}$ & $4.8 \mathrm{c}$ & $13.2 \mathrm{~d}$ & $9.7 \times 10^{3} \mathrm{c}$ & $5.0 \times 10^{3} \mathrm{~d}$ \\
PL029 (A) & $30.4 \mathrm{c}$ & $20.8 \mathrm{a}$ & $1.3 \mathrm{~b}$ & $7.9 \mathrm{a}$ & $38.5 \mathrm{~b}$ & $6.22 \mathrm{a}$ & $2.4 \mathrm{c}$ & $5.5 \mathrm{~b}$ & $14.8 \mathrm{c}$ & $10.5 \times 10^{3} \mathrm{c}$ & $5.0 \times 10^{3} \mathrm{~d}$ \\
PL064 (S) & $29.2 \mathrm{c}$ & $19.5 \mathrm{a}$ & $1.5 \mathrm{a}$ & $6.7 \mathrm{~b}$ & $40.0 \mathrm{a}$ & $7.13 \mathrm{a}$ & $2.9 \mathrm{a}$ & $5.8 \mathrm{a}$ & $16.7 \mathrm{~b}$ & $8.9 \times 10^{3} \mathrm{c}$ & $4.4 \times 10^{3} \mathrm{~d}$ \\
PL088 (A) & $32.5 \mathrm{c}$ & $17.7 \mathrm{~b}$ & $1.2 \mathrm{~b}$ & $7.8 \mathrm{a}$ & $37.4 \mathrm{~b}$ & $6.38 \mathrm{a}$ & $2.5 \mathrm{c}$ & $5.4 \mathrm{~b}$ & $15.7 \mathrm{c}$ & $12.9 \times 10^{3} \mathrm{~b}$ & $6.6 \times 10^{3} \mathrm{~b}$ \\
PL111 (A) & $31.4 \mathrm{c}$ & $16.0 \mathrm{~b}$ & $1.2 \mathrm{~b}$ & $6.5 \mathrm{~b}$ & $40.6 \mathrm{a}$ & $6.70 \mathrm{a}$ & $2.7 \mathrm{~b}$ & $5.4 \mathrm{~b}$ & $15.2 \mathrm{c}$ & $11.3 \times 10^{3} \mathrm{c}$ & $5.3 \times 10^{3} \mathrm{~d}$ \\
PL138 (S) & $32.8 \mathrm{c}$ & $16.3 \mathrm{~b}$ & $1.3 \mathrm{~b}$ & $6.2 \mathrm{~b}$ & $36.2 \mathrm{~b}$ & $6.59 \mathrm{a}$ & $2.9 \mathrm{a}$ & $4.2 \mathrm{~d}$ & $15.7 \mathrm{c}$ & $10.3 \times 10^{3} \mathrm{c}$ & $5.6 \times 10^{3} \mathrm{c}$ \\
PL146 (A) & $33.3 \mathrm{c}$ & $17.7 \mathrm{~b}$ & $1.3 \mathrm{~b}$ & $7.6 \mathrm{a}$ & $36.4 \mathrm{~b}$ & $6.18 \mathrm{a}$ & $2.2 \mathrm{~d}$ & $6.3 \mathrm{a}$ & $16.5 \mathrm{~b}$ & $12.0 \times 10^{3} \mathrm{~b}$ & $6.0 \times 10^{2} \mathrm{c}$ \\
PL185 (S) & $31.3 \mathrm{c}$ & $20.1 \mathrm{a}$ & $1.3 \mathrm{~b}$ & $6.1 \mathrm{~b}$ & $38.7 \mathrm{~b}$ & $6.96 \mathrm{a}$ & $2.7 \mathrm{~b}$ & $5.3 \mathrm{~b}$ & $14.1 \mathrm{~d}$ & $11.6 \times 10^{3} \mathrm{~b}$ & $5.9 \times 10^{3} \mathrm{c}$ \\
PL193 (A) & $33.0 \mathrm{c}$ & $16.3 \mathrm{~b}$ & $1.4 \mathrm{a}$ & $7.7 \mathrm{a}$ & $41.6 \mathrm{a}$ & $6.50 \mathrm{a}$ & $2.7 \mathrm{~b}$ & $5.3 \mathrm{~b}$ & $15.6 \mathrm{c}$ & $13.1 \times 10^{3} \mathrm{~b}$ & $6.9 \times 10^{3} \mathrm{~b}$ \\
PL216 (S) & $42.0 \mathrm{a}$ & $18.6 \mathrm{~b}$ & $1.3 \mathrm{~b}$ & $6.9 \mathrm{~b}$ & $43.1 \mathrm{a}$ & $7.19 \mathrm{a}$ & $2.9 \mathrm{a}$ & $5.0 \mathrm{c}$ & $16.7 \mathrm{~b}$ & $15.7 \times 10^{3} \mathrm{a}$ & $8.9 \times 10^{3} \mathrm{a}$ \\
PL242 (A) & $33.5 \mathrm{c}$ & $17.7 \mathrm{~b}$ & $1.4 \mathrm{a}$ & $7.6 \mathrm{a}$ & $42.6 \mathrm{a}$ & $6.90 \mathrm{a}$ & $2.9 \mathrm{a}$ & $6.3 \mathrm{a}$ & $19.4 \mathrm{a}$ & $12.3 \times 10^{3} \mathrm{~b}$ & $6.6 \times 10^{3} \mathrm{~b}$ \\
PL289 (S) & $33.1 \mathrm{c}$ & $22.0 \mathrm{a}$ & $1.2 \mathrm{~b}$ & $6.1 \mathrm{~b}$ & $38.6 \mathrm{~b}$ & $6.84 \mathrm{a}$ & $2.6 \mathrm{c}$ & $5.5 \mathrm{~b}$ & $16.2 \mathrm{~b}$ & $12.8 \times 10^{3} \mathrm{~b}$ & $7.3 \times 10^{3} \mathrm{~b}$ \\
PL297 (S) & $32.4 \mathrm{c}$ & $14.4 \mathrm{~b}$ & $1.4 \mathrm{a}$ & $6.8 \mathrm{~b}$ & $38.4 \mathrm{~b}$ & $5.04 \mathrm{~b}$ & $2.3 \mathrm{~d}$ & $4.9 \mathrm{c}$ & $16.2 \mathrm{~b}$ & $12.4 \times 10^{3} \mathrm{~b}$ & $6.3 \times 10^{3} \mathrm{c}$ \\
PL350 (S) & $34.5 \mathrm{c}$ & $17.7 \mathrm{~b}$ & $1.3 \mathrm{~b}$ & $9.1 \mathrm{a}$ & $39.7 \mathrm{a}$ & $6.43 \mathrm{a}$ & $2.5 \mathrm{c}$ & $5.0 \mathrm{c}$ & $14.9 \mathrm{c}$ & $12.5 \times 10^{3} \mathrm{~b}$ & $5.9 \times 10^{3} \mathrm{c}$ \\
Comum (A) & $37.1 \mathrm{~b}$ & $18.4 \mathrm{~b}$ & $0.8 \mathrm{~d}$ & $8.8 \mathrm{a}$ & $28.2 \mathrm{c}$ & $5.46 \mathrm{~b}$ & $2.2 \mathrm{~d}$ & $5.3 \mathrm{~b}$ & $17.9 \mathrm{a}$ & $12.1 \times 10^{3} \mathrm{~b}$ & $5.8 \times 10^{3} \mathrm{c}$ \\
\hline
\end{tabular}

Means followed by the same letter in a column belong to the same group established by the Scott- Knott test at $5 \%$ probability.

* in parentheses: reproduction mode, where (A): apomictic and (S): sexual.

PH: plant height; BL: Blade length; BW: Blade width; ShL: Sheath length; FSL: flower stem length; IAL: inflorescence axis length; NR: number of racemes; BRL: basal raceme length; NSBR: number of spikelets in the basal raceme; DMY: dry matter yield; LDMY: leaf dry matter yield. 
Table 3. Clusters of $B$. humidicola hybrids estimated by the Tocher method after eliminating the variables of least relative importance in canonical variate analysis

\begin{tabular}{lcc}
\hline Group & Hybrids & Eliminated characteristic \\
\hline I & $2,8,4,5,14,9,12,13,7,12$ & \\
II & 6 & DMY \\
III & 1 & \\
IV & 10 & NSBR \\
V & $9,13,14,4,5,2,8,7,12$ & \\
\hline I & 3,11 & \\
II & 1 e 6 & IAL \\
III & 10 & \\
IV & $2,8,5,4,9,14,13,12,7$ & \\
I & 3,11 & PH \\
II & 6 & \\
III & 1 & \\
IV & 10 & \\
V & 3,11 & \\
\hline I & 6,10 & \\
II & 1 & DMY, NSBR, IAL, PH \\
III & $8,12,4,2,5,9,14,13$ & \\
IV & 3,11 & 7 \\
I & 6,12 & \\
II & 1 & \\
III & 10 & \\
IV & 10 & \\
V & VI & \\
\hline
\end{tabular}

Hybrid identification: 1: PL003; 2: PL029; 3: PL064; 4: PL88 5:PL111; 6: PL138; 7: PL146; 8: PL185; 9: PL193; 10: PL216; 11: PL242; 12: PL289; 13: PL297; 14: PL350. DMY: dry matter yield ( $\mathrm{kg} \mathrm{ha}^{-1}$ year $\left.{ }^{-1}\right)$; NSBR: number of spikelets in the basal raceme; IAL: inflorescence axis length (cm); PH: plant height (cm).

with 36 chromosomes, considering that there is only one sexual accession identified with this ploidy and chromosome number. This restriction excludes the possibility of crosses with the apomictic commercial cultivars Comum and Llanero, which are nonaploid with 54 chromosomes (Boldrini et al. 2011).

After studying the divergence between hybrids, traits were eliminated and the effect of this elimination on the hybrid clustering assessed by canonical variate analysis (Cruz et al. 2012). The eliminated variables, in decreasing order of importance in the discrimination of hybrids, were dry matter yield, number of spikelets in basal raceme, length of the inflorescence axis and plant height. When eliminating the traits dry matter yield, number of spikelets in basal raceme and inflorescence axis length separately, the new group formation differed little from the original grouping by the Tocher method, resulting in groups similar to those from the nearest neighbor clustering prior to elimination (Table 3). The exclusion of the variable plant height did not affect the groupings. On the other hand, changes in clustering were rather marked when eliminating the four traits simultaneously (Table 3 ). An analysis of the genetic correlations between the traits studied showed that the coefficients were high between the traits dry matter yield and leaf dry matter yield (0.97); plant height and leaf dry matter yield (0.89); plant height and dry matter yield $(0.86)$; blade width and number of spikelets in basal raceme (0.78); and the inflorescence axis length and number of racemes (0.73). This result reinforces the observed redundancy between these traits and confirms the recommendation for elimination by the proposed method.

Therefore, the elimination technique can be considered effective, despite small variations, and the above characteristics were confirmed as not relevant for the genetic divergence among the genotypes studied, when discarded separately. However, the decision to eliminate variables must be analyzed very carefully (Assis et al. 2002), once the technique used in this study was not efficient in other studies of genetic divergence. In studies of genetic diversity in elephant grass (Pennisetum purpureum), Shimoya et al. (2002) found that the method of elimination using the technique of canonical variables was inefficient, since the elimination of only one trait (stem diameter) substantially altered the genotype grouping. Based on the same criteria 
in a study on genetic diversity in forage peanut (Arachis repens), Azevedo et al. (2011) excluded a less important variable (length of apical leaflet) and found that the number of groups formed decreased from six to four, and the ranking of the accessions in the group was altered, confounding the original grouping. These authors do therefore not recommend the elimination of the variable in question.

\section{CONCLUSIONS}

It was concluded that i) There is genetic variability among the agronomic and morphological characters of the evaluated $B$. humidicola genotypes; ii) the lack of genetic variability for bromatological characters indicates the need to seek differentiated strategies, e.g., the adjustment of the weights for these traits when using selection indices in the early stages of the breeding program; iii) The genetic distance between cv. Comum and intraspecific hybrids of B. humidicola is large iv) There are sexual hybrids that are divergent and superior to cv. Comum that can be recombined in new cycles of recurrent selection; v) There are apomictic hybrids that are divergent and superior to $\mathrm{cv}$. Comum that can be evaluated for animal response and are candidates for new plant varieties; vi) There are redundant variables in the data set that can be excluded from the analyses, resulting in labor and time savings.

\section{ACKNOWLEDGEMENTS}

The authors are indebted to the Associação para o Fomento à Pesquisa de Melhoramento de Forrageiras (UNIPASTO) for funding.

\title{
Divergência genética entre híbridos de Brachiaria humidicola (Rendle) Schweick avaliados na Amazônia Ocidental Brasileira
}

\begin{abstract}
Resumo - Os objetivos deste trabalho foram verificar a existência de variabilidade genética entre genótipos de Brachiara humidicola, estudar a divergência genética e identificar variáveis redundantes na discriminação dos híbridos. Foram avaliados 15 genótipos para características morfológicas, agronômicas e bromatológicas, em delineamento de blocos casualizados com seis repetições em Rio Branco, AC. Foi realizada análise de variância, seguida do teste de Scott-Knott. No estudo da divergência genética, foram empregadas diferentes técnicas de análise multivariada. Foram observadas diferenças significativas para características agronômicas e morfológicas, porém não houve variabilidade para as bromatológicas. Houve consistência entre as diferentes técnicas de agrupamento. Foram identificadas quatro características redundantes, passiveis de descarte. Conclui-se que há híbridos divergentes e superiores que podem ser utilizados em programas de seleção recorrente (sexuais) ou podem ser lançados como novas cultivares (apomíticos), após avaliações de desempenho animal. A ausência de variabilidade genética para caracteres bromatológicos indica a necessidade de estratégias diferenciadas de seleção.
\end{abstract}

Palavras-chave: Análise multivariada, forrageiras tropicais, melhoramento de forrageiras, valor nutritivo.

\section{REFERENCES}

Acre: Governo do Estado do Acre (2006) Programa estadual de zoneamento ecológico econômico do estado do Acre. Zoneamento ecológico econômico do acre fase II: documentos síntese, Escala 1:250.000. SEMA, Rio Branco, 356p.

Assis GML, Euclydes RF, Cruz CD and Valle CB (2002) Genetic divergence in Brachiaria species. Crop Breeding and Applied Biotechnology 2: 331-338.

Assis GML, Euclydes RF, Cruz CD and Valle CB (2003) Discriminação de espécies de Brachiaria baseada em diferentes grupos de caracteres morfológicos. Revista Brasileira de Zootecnia 32: 576-584.

Assis GML, Valle CB, Andrade CMS and Valentim JF (2013) Selecting new Brachiaria humidicola hybrids for Western Brazilian Amazon. Tropical Grasslands - Forrajes Tropicales 1: 42-44.

Azevedo JMA, Silva HSF, Assis GML, Santos LFA and Wolter PF (2011) Genetic divergence among accessions of Arachis repens based on vegetative morphological characteristics. Revista Brasileira de Zootecnia 40: 2067-2073.

Barbosa RA (2012) BRS Tupi: Brachiaria humidicola. Embrapa Gado de Corte, Campo Grande, 2p. (Folder).

Barcellos AO, Ramos AKB, Vilela L and Martha Junior GB (2008) Sustentabilidade da produção animal baseada em pastagens consorciadas e no emprego de leguminosas exclusivas, na forma de banco de proteína, nos trópicos brasileiros. Revista Brasileira de Zootecnia 37: 51-67.

Boldrini KR, Adamowski EV, Silva, N, Pagliarini MS and Valle CB (2011) Meiotic behavior in nonaploid accessions of Brachiaria humidicola (Poaceae) and implications for breeding. Genetics and Molecular Research 10: 169-176.

Carvalho GGP and Pires AJV (2008) Leguminosas tropicais herbáceas em associação com pastagens. Archivos de Zootecnia 57: 103-113.

Cruz CD (2006) Programa genes: Biometria. Editora UFV, Viçosa, 382p.

Cruz CD, Regazzi AJ and Carneiro PCS (2012) Modelos biométricos aplicados ao melhoramento genético - Volume 1, Editora UFV, Viçosa, 514p.

Dias-Filho MB (2006) Respostas morfofisiológicas de Brachiaria spp. ao alagamento do solo e a síndrome da morte de capim-marandu. In Barbosa RA (ed.) Morte de pastos de braquiárias. Embrapa Gado 
de Corte, Campo Grande, p. 83-112.

Figueiredo UJ, Nunes JAR and Valle CB (2012) Estimation of genetic parameters and selection of Brachiaria humidicola progenies using a selection index. Crop Breeding and Applied Biotechnology 12: 237-244.

Jollife IT (1972) Discarding variables in principal component analysis. I: artificial data. Applied Statistics 21: 160-173.

Jungmann L, Vigna BBZ, Boldrini KR, Sousa ACB, Valle CB, Resende RMS, Pagliarini MS, Zucchi MI and Souza AP (2010) Genetic diversity and population structure analysis of the tropical pasture grass Brachiaria humidicola based on microsatellites, cytogenetics, morphological characteristics, and geographical origin. Genome 53: 698-709.

Keller-Grein G, Maass BL and Hanson J (1996) Variación natural en Brachiaria y bancos de germoplasmas existentes. In Miles JW, Maass BL and Valle CB (eds.) Brachiaria: biología, agronomía y mejoramiento. CIAT, Cali, p. 116-135 (Publicación 295).

Lascano CE and Euclides VPB (1996) Calidad nutricional y producción animal em las pasturas de Brachiaria. In Miles JW, Maass BL and Valle CB (eds.) Brachiaria: biología, agronomía y mejoramiento. CIAT, Cali, p. 116-135 (Publicación 295).

Macedo MCM (2006) Aspectos edáficos relacionados com a produção de Brachiaria brizantha cultivar Marandu. In Barbosa RA (ed.) Morte de pastos de braquiárias. Embrapa Gado de Corte, Campo
Grande, p. 35-65.

Minson DJ and Milford R (1967) The voluntary intake and digestibility of diets containing different proportions of legume and mature pangola grass (Digitaria decumbens). Australian Journal of Experimental Agriculture and Animal Husbandry 7: 546-551.

Reyes-Purata A, Bolaños-Aguilar ED, Hernández-Sánchez D, ArandaIbañez EM and Izquierdo-Reyes F (2009) Producción de materia seca y concentración de proteína en 21 genotipos del pasto humidícola Brachiaria humidicola (Rendle) Schweick. Universidad y Ciencia. Trópico Húmedo 25: 213-224.

Reis RA and Silva SC (2006) Consumo de forragens. In Berchielli TT, Pires AV, Oliveira SG (eds.) Nutrição de ruminantes. Funep, Jaboticabal, p. 79-103.

Scott A and Knott MA (1974) Cluster analysis method for grouping means in the analysis of variance. Biometrics 30: 507-512.

Shimoya A, Cosme DC, Ferreira RP, Pereira AV and Carneiro CS (2002) Divergência genética entre acessos de um banco de germoplasma de capim elefante. Pesquisa Agropecuária Brasileira 37: 971-980.

Valle CB and Glienke C (1991) New sexual accession in Brachiaria. Apomixis Newsletter 7: 42-43.

Zorzatto C, Chiari L, Bitencourt GA, Valle CB, Leguizamo GOC, Schuster I and Pagliarini MS (2010) Identification of a molecular marker linked to apomixis in Brachiaria humidicola (Poaceae). Plant Breeding 129: 734-736. 